http://dx.doi.org/10.11646/phytotaxa.162.2.5

\title{
Nomenclatural notes on Tectaria blepharorachis (comb. nov.) and T. fibrillosa (Tectariaceae; Pteridophyta) for Malagasy fern flora
}

\author{
YI-FAN DUAN ${ }^{1} \&$ LI-BING ZHANG ${ }^{2 *}$ \\ ${ }^{1}$ International Cultivar Registration Center for Osmanthus, Nanjing Forestry University, Nanjing, Jiangsu, 210037, P. R. China \\ ${ }^{2}$ Chengdu Institute of Biology, Chinese Academy of Sciences, P.O. Box 416, Chengdu, Sichuan 610041, P. R. China and Missouri \\ Botanical Garden, P.O. Box 299, St. Louis, Missouri 63166-0299, U.S.A. \\ "Author for correspondence: Libing.Zhang@mobot.org
}

\begin{abstract}
While working on a monograph of Ctenitis (Dryopteridaceae) found in Madagascar we discovered that two Tectariarelated names need nomenclatural attention: the name C. poolii (C.Christensen) Tardieu-Blot is not legimate, and Dryopteris blepharorachis C.Christensen should be reinstalled from synonymy. A new combination, Tectaria blepharorachis (C.Christensen) Li Bing Zhang \& Yi F. Duan, is proposed. Line drawings of pinnae of the both related species are provided for identification purpose.
\end{abstract}

\section{Introduction}

Species of Ctenitis (C.Christensen) C.Christensen (1938: 544) (Dryopteridaceae), a fern genus previously placed in Tectariaceae, are widespread in the New and Old World wet tropics (Christensen 1938, Mickel \& Smith 2004). A morphologically similar genus Tectaria Cavanilles (1799: 115) (Tectariaceae) is frequently found in tropical regions, with most species growing terrestrially in rain forests (Ding et al. 2013). These two genera share similar hairs, but the veins of Ctenitis are free while those of Tectaria are usually anastomosing (Holttum 1983, Mickel \& Smith 2004). While preparing a monograph of Ctenitis in Madagascar, we found that two Tectaria-related names need nomenclatural attention: the name C. pooli (C.Christensen) Tardieu-Blot (1958: 330) is not legitimate, and Dryopteris blepharorachis C.Christensen, treated previously as a synonym, should be recognized with the latter transferred to Tecataria.

\section{Taxonomy}

1. Tectaria fibrillosa (Baker) J.P.Roux (2009: 194) (Figure 1).

Basionym:-Nephrodium fibrillosum Baker (1876: 418).

Type: MADAGASCAR. Antananarivo, W. Pool s.n. (holotype K-000351164!).

Homotypic synonyms:-Aspidium fibrillosum (Baker) Kuhn (1879: 65); Dryopteris poolii C.Christensen (1905: 285); Ctenitis poolii (C.Christensen) Tardieu-Blot (1958: 330), nom. illeg.; Pseudotectaria fibrillosa (Baker) Holttum (1990: 261).

Distribution: Madagascar.

When Tectaria fibrillosa was published, Ctenitis poolii was cited as a homotypic synonym by Roux (2009). The latter was based on Dryopteris poolii, a nomen novum for Nephrodium fibrillosum, the epithet being blocked by $D$. fibrillosa (Baker) C.Christensen (1905: 264) when transferred to Dryopteris. However, the epithet was available when the species was transferred to Ctenitis. Therefore, $C$. poolii is not legitimate.

Additional specimens examined:-MADAGASCAR. Antsiranana: Doany, PN DE Marojejy, $11.5 \mathrm{~km}$ sud-est de Doany, [14'25'36"S, 49 36'30"E], alt. 820 m, 14 Oct 2001, F. Rakotondrainibe \& H. Rasolohery 6226 (K, MO, P, TEF). Antsiranana: Vohemar, Daraina, Forêt de Binara, $7.5 \mathrm{~km}$ au sud-ouest de Daraina, [13 ${ }^{\circ} 15^{\prime} 12^{\prime \prime} \mathrm{S}, 49^{\circ} 37^{\prime} 12^{\prime \prime}$ 
contains at least three sheets at BM, S, and S-P, respectively. Holttum cited the one at S as the "type" (Holltum 1990) and thereby effectively lectotypified this name.

Additional specimen examined:-MADAGASCAR. Mandraka, 19 Jun 1906, Alleizette 81 (P).

\section{Acknowlegements}

We thank Fang Cui for part of the line drawings, James L. Reveal for helpful comments, the directors and curators of the herbaria BM, K, MO, NY, P, S, SING, and UC for providing access to material in their care, the Doctorate Fellowship Foundation of Nanjing Forestry University, the fellowship of the Priority Academic Program Development of Jiangsu High Education Institutions (PAPD), and the Postgraduate Innovation Project Foundation in Jiangsu, China (CXZZ12-0518) to Y.-F.D.

\section{References}

Baker, J.G. (1876) On a collection of ferns made by Mr. William Pool in the interior of Madagascar. Journal of the Linnean Society, Botany 15: 411-422. http://dx.doi.org/10.1111/j.1095-8339.1876.tb00251.x

Cavanilles, A.J. (1799) Helechos propiamente dichos, esto es, Helechos dorsíferos. Anales de Historia Natural 1: $109-115$.

Christensen, C. (1905) Index Filicum. Copenhagen: H. Hagerup.

Christensen, C. (1916) New ferns from Madagascar. Arkiv för Botanik 14: 1-8.

Christensen, C. (1938) Filicinae. Pp. 522-550 in: Verdoom, F. (ed.), Manual of Pteridology. The Hague: Nihoff.

Ding, H.H., Chao, Y.S. \& Dong, S.Y. (2013) Taxonomic novelties in the fern genus Tectaria (Tectariaceae). Phytotaxa 122: 6164. http://dx.doi.org/10.11646/phytotaxa.122.1.3

Holttum, R.E. (1983) The fern-genera Tectaria, Heterogonium and Ctenitis in the Mascarene Islands. Kew Bulletin 38: 107130. http://dx.doi.org/10.2307/4107974

Holttum, R.E. \& Lin, Y.X. (1990) A re-assessment of the fern genus Pseudotectairia. Kew Bulletin 45: $257-263$. http://dx.doi.org/10.2307/4115683

Kuhn, M. (1879) Cryptogamae vasculares. In: Ascherson, P.F.A. Ascherson, P.F.A., Boeckeler, J.O., Klatt, F.W., Kuhn, F.A.M., Lorentz, P.G. \& Sonder, O.W., Von der Decken's Reisen in OstAfrica, 3, 3, Botanik. Leipzig: C.F. Winter. pp. 7-71.

Mickel, J.T. \& Smith, A.R (2004) The pteridophytes of Mexico. Memoirs of the New York Botanical Garden 88: 1-1055.

Roux, J.P. (2009) Synopsis of the Lycopodiophyta and Pteridophyta of Africa, Madagascar and neighbouring islands. Strelitzia 23. Pretoria: South African National Biodiversity Institute.

Tardieu-Blot, M.L. (1958) Famille 5: Aspidiacées. Pp. 302-391 in: Hubert, H. (ed.), Flore de Madagascar et des Comores, vol. 1. Paris: Typographie Firmin-Didot et Cie. 